International Journal of Instruction e-ISSN: 1308-1470 • www.e-iji.net
October $2017 \bullet$ Vol.10, No.4

p-ISSN: 1694-609X

pp. 379-398

Received: 07/06/2017

Revision: 08/08/2017

Accepted: 13/08/2017

\title{
Teachers' Attitudes towards Teaching English Grammar: A Scale Development Study
}

\author{
Murat Polat \\ Dr., Anadolu University, Turkey, mpolat@anadolu.edu.tr
}

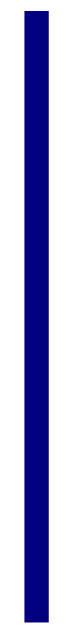

In most ELT classes, the importance of grammar, how it should be taught or how much it should be integrated into language teaching are still matters of discussion. Considering this fact, learning teachers' attitudes towards teaching grammar is significantly valuable for researchers. This study thus aimed to design a scale that identifies teachers' attitudes towards the role of grammar in the process of teaching English, to pilot it, and to find out the psychometric qualities like reliability and validity of the scale designed. The scale was developed in two phases; it was first aimed to explore the factor structure of the scale, then to confirm the structure gained from the exploration of the items. The study was carried out in 2015 and 247 volunteer language teachers from 3 state universities in Eskişehir and Kütahya were included. The results of exploratory and confirmatory factor analyses revealed that the scale developed in this study was a considerably valid and reliable data collection tool including three factors. Finally, the analyses indicated that gender and graduate faculties did not create significant differences whereas age and the degrees obtained by the teachers created a considerable difference on language teachers' attitudes towards grammar teaching $(\mathrm{p}<.05)$.

Keywords: grammar, teacher attitude, scale development, exploratory factor analysis, confirmatory factor analysis

\section{INTRODUCTION}

The debate on the prime role of grammar knowledge in language learning and its reflections on the educational outcomes has been a matter of research for some time. In countries like Turkey where grammar translation method in teaching has been the most popular medium of language education, the ways how to teach grammar and the ideas on how to make it more meaningful and fruitful have become a significant concern. To illustrate, while teaching grammar, some instructors prefer to use their native tongues rather than English to make the instructions clearer and more understandable for the learners. In addition, some others prefer immediate grammar error correction in language classes to underline the importance of accurate language use. However, in the

Citation: Polat, M. (2017). Teachers' Attitudes towards Teaching English Grammar: A Scale Development Study. International Journal of Instruction, 10(4), 379-398. https://doi.org/10.12973/iji.2017.10422a 
same language teaching contexts minority of teachers still believe that grammar is an integral part of speaking, reading and writing, and should only be given in reading texts, communicative dialogues, sample essays and listening practices. All those different teaching perspectives derive us to the point that if the attitudes of teachers are studied, it will be easier and more rationalistic to see the role of grammar in language teachers' minds.

\section{Literature review / Theoretical background}

In most language classes, the necessity of grammar teaching and the ways to integrate it into foreign language learning is a crucial matter that many researchers have studied (Doughty \& Williams, 1998; Ellis, 2006; Thornbury, 1997). Those researchers in the field consider grammar teaching vital and its importance was accepted as an indispensable component of language teaching. Ellis (2006) for example claims that implicit instruction and traditional forms of grammar teaching will enable the learners gain some automatic self-check systems that will help them create accurate grammar forms. Thus it is believed that learners should in a way see, acquire and use various forms of target language in order to make them a part of their interlanguage to be used whenever needed. Similarly, Lightbown (1991) called grammar instructions as a 'hook' for learners by which they could form a basis to build up their proficiency in producing utterances in English. Ur (1996) also noted that the learners could later use the implicitly taught grammatical forms unconsciously in oral and written contexts if they are provided with correct grammatical forms with numerous examples and certainly enough chance to practice.

However rather than the existence of grammar teaching in language classes, the ways on how to teach grammar has been the real matter of discussions up to now since the basic role of grammar in teaching a foreign language has been a controversial issue over the years. Grammar teaching and grammatical accuracy have been considered as the basic elements to help learners communicate in the target language. However, with the introduction of Communicative Approach in the 1970s, the way how teachers see grammar in language learning changed and the language programs had to revise their syllabi considering the merits of communicative practices (Loewen et al, 2009). More contextual and interactive books and techniques appeared to let the practitioners teach grammar meaningfully. Similarly, in the following years Krashen (1982) asserted that grammar is a phenomenon that can be gained naturally with meaningful instructions and claimed that language classes where simply grammar rules are taught are nothing more than a waste of time. Many others supported this claim, whereas criticized as well. For instance, Al-Mekhlafi, and Nagaratnam (2011) claim that grammar teaching is not simply a way to transfer some rules to student but a way to let them understand how the language is formed by themselves. Nonetheless, instructional grammar, which was not supported by realia and contextual language, did not make much difference on students' language development (Hedge, 2000). Contextual and meaningful language teaching made a great impact on language teachers and with this new trend, it was planned to achieve that learners should have a chance to use language they learnt in a real context with native speakers (Borg, 2003;Canale \& Swain, 1980) but it was nothing more than a 
utopia for the learners in Turkey. Therefore, language teachers have to design or edit various forms of teaching grammar through games, videos, pictures, etc. in order to make grammar teaching a part of meaningful learning.

In an attitude study done by Uysal \& Yavuz (2015) it was found that novice teachers show an affirmative attitude towards grammar teaching although they strongly believe that it should not be taught directly or overtly. Attitudes of the participants differ depending on the age and purpose of the learners. It was also seen that there is a gap between the practice and theory the reason of which may be the testing policy in Turkish educational system. Azad (2013) also stated similar facts and underlined the finding that grammar should not be taught directly and beliefs of grammar teachers should differ considering their backgrounds and teaching expertise.

Thu (2009) stated that grammar is believed to be best taught explicitly, inductively or deductively, but not implicitly. In that study it was found that participant teachers tend to value error correction, and they seem to believe that grammar errors should be corrected even when they do not interfere with comprehensibility. It was also found that the teachers generally believe in the negative influence of first language (L1) on second language (L2), but they do not tend to believe in the positive influence of L1 on L2. Finally, the teachers believe that their previous training and the materials they use greatly improved their confidence and skills in teaching grammar. Furthermore in her study, Zaal (2013) stated that the participants mostly rely on teaching grammar from the textbooks given to them and keep track with the syllabus they were given. In her study it was also stated that language teachers mostly do not follow the recent trends in language teaching and mostly willing to keep up with the course schedule. Considering those findings, 3 important factors in grammar teaching worth studying. The role of methodology (how much grammar, implicit or explicit grammar teaching and the use of native or target language in grammar lessons), error correction techniques \& frequency of correction and finally the materials ought to be used in grammar classes tend to be the main factors of a survey to be used in order to gather the attitudes of language teachers towards teaching grammar.

\section{Research questions}

The aim of this study was twofold. Firstly, it was aimed to develop an authentic scale to investigate the teachers' attitudes towards grammar teaching. This newly designed scale is hoped to contribute to other belief studies in ELT since in different educational contexts different tools to measure attitudes are needed. Secondly, those participants" attitudes towards grammar teaching were examined based on several independent variables. The research questions of the study were listed as:

1. What are the exploratory factor analysis results of Teachers' English Grammar Attitude Scale (TEGAS)?

2. What are the confirmatory factor analysis results of Teachers' English Grammar Attitude Scale (TEGAS)?

3. What are the reliability test results of Teachers' English Grammar Attitude Scale (TEGAS)? 
4. Is there a significant difference in teachers' attitudes towards teaching grammar according to their gender, age, graduate faculties and degrees obtained?

\section{METHOD}

To collect teachers' attitudes on teaching grammar, the purpose of this study was to create an authentique scale to gather data on teachers' beliefs on grammar teaching, to identify their personal attitudes and to test if these attitudes towards grammar teaching differ considering a number of independent variables such as gender, age, experience, graduate faculties and academic degrees of the participants.

\section{Participants}

This scale was developed with the contribution of 247 voluntary participants working in the language schools of three state universities in Eskişehir and Kütahya, cities of Turkey. The participants who were aged between 22-51 were all English language instructors and $63 \%$ of them were females while $37 \%$ were males. The participants were mostly ELT graduates (76\%), however there were also graduates from English Literature and Translation and Interpretation Studies. The sampling technique used in the study was stratified sampling technique as the participants' years of teaching English and their educational levels varied. $57 \%$ of the participants had a teaching experience between $1-10$ years, $32 \%$ of the participants had a teaching experience between 11-20 years and $11 \%$ of the participants had a teaching experience more than 21 years. $51 \%$ of those participants held a BA, $40 \%$ held an MA and the rest 9\% had PHD when this study was carried out. To verify the data obtained from participants the group of teachers was divided in two, the former group to be used in the exploration of the psychometric properties of the scale items in terms of the construct's validity and reliability, and the latter to check if the factor structure gained from the scale would be confirmed.

Group I: The first group was formed so as to find out the scale's psychometric properties and the focus was on its construct validity and reliability (internal validity, Cronbach Alpha coefficient). The participants of this group were the teachers of language schools of Anadolu University in Eskişehir, Dumlupınar University in Kütahya and Eskişehir Osmangazi University and the data collection period was the spring term of 2014-2015 educational year. The pilot study of the scale development process was conducted in June 2015. The data were collected from 119 teachers from these schools.

Group II: The second group was formed both to check if the factor structure determined in the data of the first group was confirmed, and to examine teachers' attitudes towards grammar teaching, based on a number of independent variables such as gender, age, graduate faculties and degrees obtained. Second group's participants were another group of teachers working at the language schools of Anadolu, Dumlupınar Eskişehir Osmangazi Universities, The participants were all chosen among the ones who did not participated to the first EFA phase of the study. The data were collected from 128 teachers in October, 2015. The participation of one teacher from Anadolu, University and 3 from Dumlupinar and Osmangazi Universities were not accepted since some relevant personal information parts of those teachers in the forms were missing. In sum 
including all the participants of both groups, out of 251 teachers who were willing to contribute to the study, 247 were included.

\section{Instruments}

Depending on the number of included items, the target participants, required time and sociological variables, the steps of developing a scale would vary. In some studies, only the confirmation of some experts in the field was considered satisfactory while a great many steps were required in the creation of a new scale in some others. Though there is not a clear agreement on its process, researchers considered that a reliable scale should be developed in a number of steps (Cohen \& Swerdlik, 2013; Crocker \& Algina, 1986; DeVellis, 2014; Şeker \& Gençdoğan, 2014). The 8 steps listed below were followed to develop a five point Likert Scale named as Teachers' English Grammar Attitude Scale (TEGAS):

(1) Objective, participant groups and the time needed were defined.

(2) The focus and content of the scale were described.

(3) A bunch of items were written based on the scope and content of the scale.

(4) The items were checked and corrections and exclusions were made.

(5) Data collection and analysis methods were identified.

(6) The scale was piloted in the scale development group ( $1^{\text {st }}$ Group)

(7) The factor structure was tested in the scale confirmation group ( $2^{\text {nd }}$ Group)

(8) Comparing the findings and analyzing the data on the results

\section{Data collection procedures}

In the initial phase, the aim and the content of the study were explained to the contact people working in those schools to invite their colleagues to contribute to the study. Then, the number of teachers working in the 3 language schools were taken and it was assumed that a total of 230-240 participants could be well enough to develop the scale (247 participants' responses were used). The time that would be spent for the whole study was planned to be around 10 months. Since the focus of the study was to collect teachers' attitudes towards grammar teaching, a thorough literate review was made to identify the rationale behind teaching grammar, the way the teachers consider grammar teaching and the findings of the previous studies on how their attitudes vary towards grammar teaching. After the review, 32 items were written on grammar teaching including some preferences of Turkish teacher like using L1 in teaching grammar rules, making translations while exemplifying or comparing the grammars of L1 and L2 for awareness raising. 3 experts including a professor and two associate professors working in ELT checked the items and they agreed that 12 of them should be excluded since they were overlapping with other items or questioning the teaching of other skills like vocabulary or reading. In the next step data from Group 1 were collected and analyzed. 3 months later, to check and confirm the factor structure determined in the data of the first group, data from Group 2 were collected and analyzed.

\section{Data analysis}

For the statistical analysis of the data IBM-SPSS 21 and IBM-AMOS programs were used respectively, also Kaiser-Meyer-Olkin (KMO) and Bartlett Sphericity tests to 
assess the appropriateness of using factor analysis on the collected data, varimax rotation, anti-image correlation, Cronbach Alpha coefficient, and confirmatory factor analysis in order to find out the validity and reliability of TEGAS were used. In the following step, in order to define whether the attitudes of teachers towards teaching grammar differ according to a number of variables like gender, age, graduate faculties and degrees obtained, a number of statistical comparisons were intended to be made by using t-test and ANOVA. Before the above mentioned tests were done KolmogorovSimirnov and Shapiro-Wilk tests were made to test the normality of the data, however, it was noticed that the scores in each factor gathered from the 3 language schools did not show a statistically normal distribution $(\mathrm{p}<.05)$. That is why, rather than using t-test and ANOVA, which were parametric tests, nonparametric tests such as Mann Whitney U and Kruskal Wallis were preferred since a number of researchers recommended doing so (Büyüköztürk, 2013; Doğan \& Doğan, 2014; Green \& Salkind, 2008; Özdamar, 2013; Siegel, 1977).

\section{FINDINGS}

\section{Construct Validity (Exploratory Factor Analysis)}

In the process of scale development the first step was to check the availability of the data to do factor analysis. Thus the data collected from Group 1 were analyzed to find out whether they are suitable for factor analysis or not (Büyüköztürk, 2013; Doğan \& Doğan, 2014; Özdamar, 2013). Principal component analysis method was preferred to determine the construct validity of TEGAS. To do so, KMO (Kaiser-Meyer-Olkin) Test and Bartlett Sphericity Tests were conducted in principal component analysis in order to identify whether the data were appropriate for factor analysis. In addition to these statistical features varimax rotation method was also used to take a better view of factors in the statistical analysis. KMO value calculated was 0.879. A value of KMO more than 0.50 shows that the data of the study are appropriate for the implementation of factor analysis. As for the Bartlett Test, the result was [ $\left.\chi^{2}=1855.881 ; \mathrm{df}=118, \mathrm{p}<0.01\right]$. The test's significance was found less than 0.05 and it shows that factor analysis can be conducted. The factor analysis results gained with principal component analysis method showed that items 2, 13, 14 and 17 demonstrated lower factor loads than the critical value (0.300) in terms of total item correlation. Moreover, items 3 and 4 made up of another factor together. The accepted structure for factor combination in the literature expects that each factor consist of three or more items in order to contribute to the phenomenon that could be explained by the scale, and they are supposed to have high factor loads (Özdamar, 2013). Including the items 2, 3, 4, 13, 14, 17; totally six items were taken out of the scale. In Table 1, it can be seen that the calculated factor loads of the remaining 14 items range from 0.308 and 0.807 and their item total correlations differ between 0.309 and 0.629 . The variance of the two factors appeared as a result of varimax rotation method explains the attitudes of learners towards English grammar up to $57.266 \%$. Item factor loads and total correlations are given in Table 1. 
Table 1

Initial Factor Load Loads and Item Total Correlation Results

\begin{tabular}{|c|c|c|c|c|c|}
\hline $\begin{array}{l}\text { Item } \\
\text { No }\end{array}$ & $\begin{array}{l}\text { Initial Factor } \\
\text { Load Value }\end{array}$ & $\begin{array}{l}\text { Item Total } \\
\text { Correlation }\end{array}$ & $\begin{array}{l}\text { Item } \\
\text { No }\end{array}$ & $\begin{array}{l}\text { Initial Factor } \\
\text { Load Value }\end{array}$ & $\begin{array}{l}\text { Item Total } \\
\text { Correlation }\end{array}$ \\
\hline I1 & 0.761 & 0.319 & I11 & 0.487 & 0.377 \\
\hline I5 & 0.649 & 0.629 & I12 & 0.411 & 0.465 \\
\hline I6 & 0.807 & 0.388 & I15 & 0.560 & 0.613 \\
\hline I7 & 0.595 & 0.336 & I16 & 0.592 & 0.309 \\
\hline I8 & 0.324 & 0.354 & I18 & 0.717 & 0.340 \\
\hline I9 & 0.603 & 0.500 & I19 & 0.470 & 0.371 \\
\hline I10 & 0.527 & 0.378 & I 20 & 0.514 & 0.468 \\
\hline
\end{tabular}

To sum up, the results of exploratory factor analysis in terms of the initial factor loads and item total correlation statistics, initial factor loads of the remaining items calculated in the scale were more than 0.308 and item total correlation values were more than 0.309 . Finally, the total variance that could be explained with this factor structure is $57 \%$ and as Büyüköztürk (2013) stated, all these values could be well accepted for the scale development studies in social sciences. In the next step, anti- image values of the items were calculated. Table 2 reveals the anti-image values of TEGAS items.

Table 2

Anti-image Correlation Values of Items

\begin{tabular}{llll}
\hline Item No & Anti-image & Item No & Anti-image Correlation \\
\hline I1 & 0.951 & I11 & 0.825 \\
I5 & 0.809 & I12 & 0.762 \\
I6 & 0.791 & I15 & 0.838 \\
I7 & 0.906 & I16 & 0.914 \\
I8 & 0.918 & I18 & 0.931 \\
I9 & 0.836 & I19 & 0.906 \\
I10 & 0.873 & I20 & 0.887 \\
\hline
\end{tabular}

It can be concluded from the analysis that anti-image correlation values of TEGAS items vary between 0.791 and 0.951 . Of the items included in the scale, none had a value less than 0.50 and this result proves the fact that factor load values of the included items contribute significantly to the factor structure of the scale.

To be able to find out the possible subcategories and which items in the scale formed up those subcategories, varimax rotation method was applied in the exploratory factor analysis because as it is stated in the literature varimax rotation could enable the researchers to simplify the expression of a particular structure in terms of a number of major factors including items (Büyüköztürk, 2013; Özdamar, 2013). As a result of this method, three factors were identified in the scale TEGAS. In addition, varimax rotation in Table 3 clearly identifies that TEGAS has 3 factors. 
Table 3

TEGAS Factors After Varimax Rotation With Items

\begin{tabular}{lccc}
\hline & \multicolumn{2}{c}{ Factors } \\
\cline { 2 - 3 } I18 & 1 & 2 & 3 \\
\cline { 2 - 3 } I20 &, 828 & & \\
I16 &, 697 & & \\
I19 &, 696 & & \\
I10 &, 587 & & \\
I12 &, 583 & & \\
I15 &, 555 & & \\
I6 & &, 845 & \\
I7 & &, 749 & \\
I5 & &, 661 & \\
I8 & &, 505 &, 867 \\
I1 & & &, 697 \\
I11 & & &, 673 \\
I9 & & & \\
\hline
\end{tabular}

After the rotation it was seen that,

- items 10,12,15,16,18,19 and 20 created the first subcategory (Factor 1). When the content of these items in this factor were checked, it was understood that these items were related with the ways of teaching grammar, the difficulties faced both by the learners and the teachers and the language choice while teaching grammar. Therefore, this factor was called as "Teachers' Attitudes Towards the Methodology of Grammar Teaching" (Grammar Methodology- GM) and the items in this factor were renumbered as $3,4,5,6,9,10$ and 13 .

- items 5,6,7 and 8 created the second subcategory (Factor 2). When the content of these items in this factor were checked, it was understood that these items were related with the types and contents of the materials that could be used while teaching grammar. Therefore, this factor was called as "Language Materials That Could Be Used While Teaching Grammar" (Materials In Grammar Teaching- MGT) and the items in this factor were renumbered as 2,7,8 and 12 .

- items 1,9,11 created the third subcategory (Factor 3). When the content of these items in this factor were checked, it was understood that these items were related with teachers' attitudes towards error correction and its impacts while teaching grammar. Therefore, this factor was called as "Error Correction in Grammar Teaching" (Grammar Error Correction- GEC) and the items in this factor were renumbered as 1, 11, 14.

\section{Confirmatory Factor Analysis}

In the last step of the development of TEGAS, in order to approve the factor structure of the scale gained from exploratory factor analysis, a final confirmatory factor analysis was made. The model of the scale after this analysis can be seen in Figure 1. 


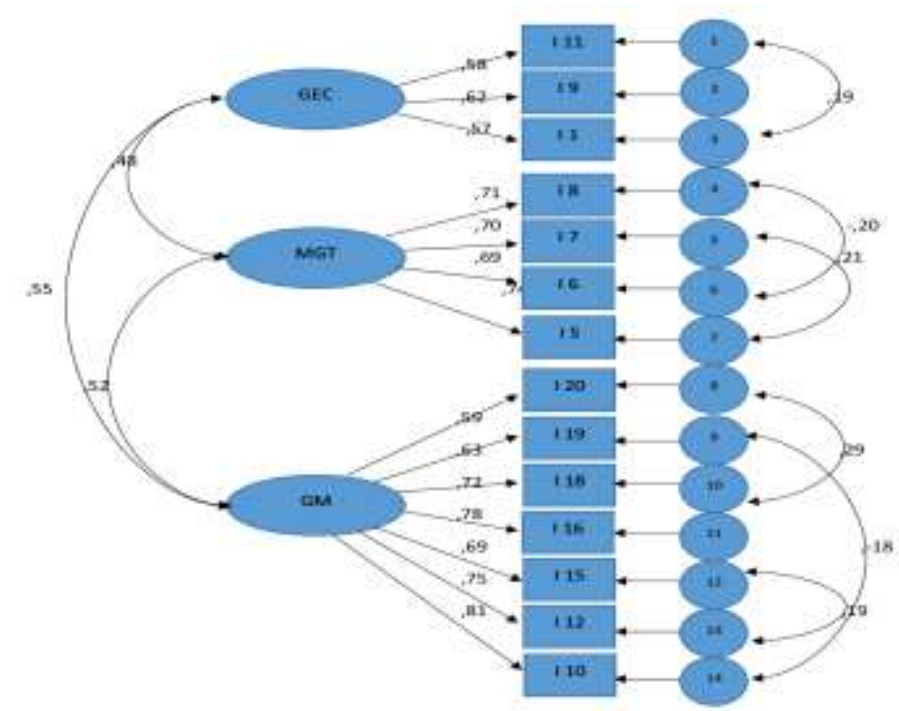

Figure 1

Confirmatory Factor Analysis Model of TEGAS (With Standardized Values)

(Figure 1 Abbreviations: GM: Grammar Methodology, MGT: Materials in Grammar Teaching, GEC: Grammar Error Correction)

Confirmatory factor analysis (CFA) results indicate the structure of TEGAS with the number of factors and the correspondent items was confirmed. From the analyses it was also calculated that Chi-square and degree of freedom values were $\chi^{2}=238.070$, $(\mathrm{df}=127, \mathrm{p}<.01)$ and finally $\chi^{2} / \mathrm{df}=2.38$ ratio was found. According to the related literature when the ratio gained from the selected structure is lower than the value of 3 , this would mean a perfect match (Browne \& Cudeck, 1993; Çokluk, Güçlü \& Büyüköztürk, 2008; Jöreskog \& Sörbom, 1993; Kline, 2005; Vieira, 2011). Thus, it can be concluded for TEGAS that the match between the data set and the model found after CFA is perfect.

One of the mostly used criterion in checking the goodness of fit of a CFA analysis is to consider RMSEA (root mean square error of approximation) values. It is advised that in CFA gaining a 0.05 or a lower value of RMSEA could be indicator of the perfect match between the data set and the acquired model but it must be also noted that this value could also be acceptable up to the value of 0.08 ( $\mathrm{Hu} \&$ Bentler, 1999; Marsh, Balla \& Hau, 1996; Şimşek, 2007; Sümer, 2000). The acquired RMSEA value in CFA of TEGAS was 0.064 , which was considered as acceptable.

Other important criteria in checking the goodness of fit of a CFA analysis is to consider the AGFI (Adjusted Goodness of Fit Index) and RMR (Root mean square residual) values. According to the experts an AGFI index higher than 0.80 and a RMR value less 
than 0.10 could be acceptable to confirm the match between data set and the acquired model (Anderson \& Gerbing, 1984; Glaser, 2002; Marsh, Balla \& Hau, 1996; Hu \& Bentler, 1999). The CFA analyses of TEGAS revealed that AGFI $=0.898$ and $\mathrm{RMR}=0.067$. When the critic limits for these values are considered, it could be stated that the match between the model and the data set is a good match and could be acceptable in terms of its results.

The final criterion in checking the goodness of fit of a CFA analysis is to consider CFI (Comparative Fit Index) index. It is commonly recommended that an index value of CFI 0.95 or higher in CFA could be considered as a "perfect match" between the data set and the model (Anderson \& Gerbing, 1984; Bentler, 1990; Hu \& Bentler, 1999; Sümer, 2000; Şimşek, 2007). Accordingly the statistical analysis in this study showed that the CFI value was 0.943 . Finally, when the acquired CFI value is checked it may be inferred that the match between the data set and the model for TEGAS was quite acceptable. The summary of goodness of fit values for TEGAS gained in CFA were given in Table 4.

Table 4

Goodness of Fit Values Gained in CFA

\begin{tabular}{lllllll}
\hline$\chi^{2}$ & $\mathrm{D}_{\mathrm{f}}$ & $\chi^{2} / \mathrm{D}_{\mathrm{f}}$ & RMSEA & AGFI & RMR & CFI \\
\hline 238.070 & 127 & 2.38 & 0.064 & 0.898 & 0.067 & 0.943 \\
\hline
\end{tabular}

The main objective in implementing CFA is to identify the level of match between a predetermined model and the actual data set (Hu \& Bentler, 1999; Sümbüloğlu \& Akdağ, 2009). Thus, it can be summarized that considering the values the goodness of fit indices revealed in CFA, it might be concluded that the 3-factor structure of TEGAS was confirmed statistically.

\section{Reliability (Cronbach Alpha) Test of the Scale}

The results of EFA revealed that that there we 3 factors in TEGAS contributing to the attitudes of teachers of English while teaching grammar and totally 14 items were present under those factors. The reliability vales of these 14 items grouped in factors named as GM (Grammar Methodology), MGT (Materials in Grammar Teaching) and GEC (Grammar Error Correction) were presented in Table 5.

Table 5

Reliability Test of 3-Factor TEGAS

\begin{tabular}{lc}
\hline Items & Cronbach Alpha \\
\hline GM (Grammar Methodology) & 0.787 \\
\hline MGT (Materials in Grammar Teaching) & 0.711 \\
\hline GEC (Grammar Error Correction) & 0.706 \\
\hline
\end{tabular}

In the literature, it is advised that a reliability level of 0.70 or above would signal high reliability (Özdamar, 2013; Sümbüloğlu \& Akdağ, 2009). Thus, all 3 factors of TEGAS could be considered highly reliable in terms of collecting data to study the attitudes of teachers in teaching grammar. 
Teachers' Attitudes Towards Grammar Teaching According to Different Independent Variables

In this part of the study, the data gathered from the second group of participants in the final form of TEGAS (after all necessary modifications were made) were statistically analyzed to find out teachers' attitudes towards teaching grammar considering a number of variables including gender, age, graduate faculties and degrees obtained.

\section{Attitudes towards teaching grammar according to gender}

Gender was considered as the first possible independent variable that could affect teachers' attitudes towards teaching English grammar. To do this, Mann Whitney U Test was done to see if there was a significant difference among the responses of teachers'. The results of the test were presented in Table 6 .

Table 6

Effect of Gender on Teachers' Attitudes Towards Grammar Teaching

\begin{tabular}{lllllcc}
\hline Factors & Gender & N & Rank Mean & Rank Sum & U & p \\
\hline \multirow{2}{*}{ GM } & Female & 87 & 82,68 & 7193.00 & \multirow{2}{*}{2414.000} & 0.311 \\
& Male & 41 & 38.34 & 1572.00 & & \\
\multirow{2}{*}{ MGT } & Female & 87 & 80.73 & 7023.00 & 2228.000 & 0.194 \\
& Male & 41 & 37.65 & 1543.00 & & \\
\multirow{2}{*}{ GEC } & Female & 87 & 81.02 & 7048.00 & \multirow{2}{*}{2235.000} & 0.107 \\
& Male & 41 & 39.24 & 1609.00 & &
\end{tabular}

Abbreviations: GM: Grammar Methodology, MGT: Materials in Grammar Teaching, GEC: Grammar Error Correction

From the results given in Table 6 it can be concluded that that gender does not play an important role on the attitudes of teachers towards grammar teaching and therefore does not create a significant difference in their attitudes $(\mathrm{p}<.05)$.

Attitudes towards teaching grammar according to age

The second independent variable that might affect the teachers' attitudes towards teaching grammar was defined as age. The effect of age was examined by using Kruskal Wallis Test since there were more than two sub-categories. The results of the analysis were presented in Table 7.

Table 7

Effect of Age on Teachers' Attitudes Towards Grammar Teaching

\begin{tabular}{lllllll}
\hline Factors & Age & $\mathrm{N}$ & Rank Mean & $\mathrm{X}^{2}$ & $\mathrm{p}$ & Significant \\
\hline \multirow{3}{*}{ GM } & $1.22-29$ & 62 & 59.67 & & & $1-2$ \\
& $2.30-37$ & 41 & 39.98 & 11.451 & 0.001 & $1-3$ \\
& $3.38+$ & 25 & 30.21 & & & $2-3$ \\
\multirow{3}{*}{ MGT } & $1.22-29$ & 62 & 61.13 & & & \\
& $2.30-37$ & 41 & 38.02 & 8.312 & 0.039 & $1-3$ \\
& $3.38+$ & 25 & 29.40 & & & \\
\multirow{5}{*}{ GEC } & $1.22-29$ & 62 & 60.78 & & & $1-2$ \\
& $2.30-37$ & 41 & 37.76 & 8.633 & 0.034 & $1-3$ \\
& $3.38+$ & 25 & 27.07 & & & \\
\hline
\end{tabular}


Abbreviations: GM: Grammar Methodology, MGT: Materials in Grammar Teaching, GEC: Grammar Error Correction)

The findings reveal that age creates a significant difference in the attitudes of teachers' towards teaching grammar. To identify the difference among sub-groups Dunn Test, a non-parametric multiple comparison test (post hoc), was made to reveal in which groups a significant difference in the attitudes occurred (Doğan \& Doğan, 2014; Şimşek, 2007). When each factor is examined individually, it can be seen that in terms of the methodology of teaching grammar (GM) teachers' attitudes differ within all age groups $(\mathrm{p}<.05)$. In terms of the materials to be used in grammar lessons, a significant difference was seen between the teachers who are over 38 and the teachers aged between 22-29 $(\mathrm{p}<.05)$. Therefore it can be referred that junior teachers attitudes on using materials in grammar lessons is significantly different from the teachers who are over 38. Considering error correction in grammar lessons, significant differences were observed between the teachers who are over 38 and the teachers aged between 22-29 and teachers between $30-37(p<.05)$. Finally, by the help of the above results it will possible to say that especially language teachers over 38 may have significantly different attitudes towards grammar teaching than their younger colleagues.

Attitudes towards teaching grammar according to work experience

Another independent variable that might affect teachers' attitudes towards teaching grammar was defined as work experience. The effect of experience was examined by using Kruskal Wallis Test since there were more than two sub-categories. The results of the analysis were presented in Table 8.

Table 8

Effect of Work Experience on Teachers' Attitudes Towards Grammar Teaching

\begin{tabular}{cllllll}
\hline Factors & Years & $\mathrm{N}$ & Rank Mean & $\mathrm{X}^{2}$ & $\mathrm{p}$ & Significant \\
\hline \multirow{3}{*}{ GM } & $1.0-7$ & 29 & 29.37 & & & $1-2$ \\
& $2.8-15$ & 64 & 59.03 & 10.953 & 0.001 & $1-3$ \\
& $3.16+$ & 35 & 38.47 & & & $2-3$ \\
\hline \multirow{3}{*}{ MGT } & $1.0-7$ & 29 & 29.37 & & & \\
& $2.8-15$ & 64 & 59.03 & 9.522 & 0.023 & $1-3$ \\
& $3.16+$ & 35 & 38.47 & & & \\
\hline \multirow{3}{*}{ GEC } & $1.0-7$ & 29 & 29.37 & & \multirow{2}{*}{0.041} & $1-2$ \\
& $2.8-15$ & 64 & 59.03 & & & \\
\hline
\end{tabular}

Abbreviations: GM: Grammar Methodology, MGT: Materials in Grammar Teaching, GEC: Grammar Error Correction

The findings reveal that experience creates a significant difference in the attitudes of teachers' towards teaching grammar. To identify the difference among sub-groups Dunn Test, a non-parametric multiple comparison test (post hoc), was made to reveal in which groups a significant difference in attitudes occurred (Doğan \& Doğan, 2014; Şimşek, 2007). When each factor is examined individually, it can be seen that in terms of the methodology of teaching grammar (GM) teachers' attitudes differ within all experience 
groups $(\mathrm{p}<.05)$. In terms of the materials to be used in grammar lessons, a significant difference was seen between the teachers who have a work experience over 16 years and the teachers who have a work experience less than 7 years $(p<.05)$. Therefore it can be referred that junior teachers attitudes on using materials in grammar lessons is significantly different from the teachers who are highly experienced. Considering error correction in grammar lessons, significant differences were observed between the teachers who have a work experience over 16 years, the teachers experienced between 8-15 years and teachers who have a work experience less than 7 years $(\mathrm{p}<.05)$. Finally, by the help of the above results it can be concluded that experienced language teachers (experience over 16 years) have significantly different attitudes towards grammar teaching than their younger colleagues.

\section{Attitudes towards teaching grammar according to graduate faculties}

A teacher's college education could have a great impact on his/her teaching skills, beliefs and attitudes. Considering this fact, the type of faculty that the participants' of this study graduated from was considered as another independent variable to check. Therefore, a Kruskal Wallis Test was applied to see if the type of faculty causes a difference in teachers' attitudes. The results driven from the analysis were summarized in Table 9.

Table 9

Effect of Graduate Faculty on Teachers' Attitudes Towards Grammar Teaching

\begin{tabular}{llllccc}
\hline Factors & Graduate & $\mathrm{N}$ & Rank Mean & $\mathrm{X}^{2}$ & $\mathrm{p}$ & Significant \\
\hline \multirow{3}{*}{$\mathrm{GM}$} & 1. ELT & 62 & 42.23 & & & \\
& 2. Eng. Lit. & 41 & 36.15 & 3.605 & 0.136 & \\
& 3. Translation & 25 & 27.92 & & & \\
\multirow{3}{*}{ MGT } & 1. ELT & 62 & 47.32 & & & \\
& 2. Eng. Lit. & 41 & 34.28 & 4.002 & 0.651 & \\
& 3. Translation & 25 & 29.67 & & & \\
\multirow{3}{*}{ GEC } & 1. ELT & 62 & 50.43 & & & \\
& 2. Eng. Lit. & 41 & 40.58 & 3.633 & 0.254 & \\
& 3. Translation & 25 & 32.28 & & &
\end{tabular}

Abbreviations: GM: Grammar Methodology, MGT: Materials in Grammar Teaching, GEC: Grammar Error Correction, ELT: English Language Teaching, Eng. Lit.: Department of English Literature, Translation: Department of Translation Studies

The results in Table 9 reveal that graduate faculty of teachers does not create a significant difference in their attitudes towards grammar teaching in any of the factors of TEGAS $(\mathrm{p}<.05)$. This is an important finding since the faculty of teachers and the variety of education they took were supposed to have some impacts that might cause a difference; however, the results show us that there is no statistically significant difference among their attitudes towards teaching grammar and the reason lying behind this result could be the content of language education in the language school they work, implementing a common syllabus or doing common exams and the obligation to teach the same things in similar ways etc. 


\section{Attitudes towards teaching grammar according to education levels}

Another crucial variable that could affect teachers' attitudes was considered as the degrees obtained by the teachers. A teacher who holds a PhD might have had at least 10 years more education than a teacher who holds a BA, thus to see if the participants' degrees create a difference in their attitudes towards grammar teaching a Kruskal Wallis Test was applied. The results of the test were given in Table 10.

Table 10 Effect of Degrees on Teachers' Attitudes Towards Grammar Teaching

\begin{tabular}{lllllll}
\hline Factors & Degree & $\mathrm{N}$ & Rank Mean & $\mathrm{X}^{2}$ & $\mathrm{p}$ & Significant \\
\hline \multirow{3}{*}{$\mathrm{GM}$} & 1. BA & 73 & 42.23 & & & \\
& 2. MA & 44 & 56.15 & 8.362 & 0.014 & $1-2$ \\
& 3. PhD & 11 & 57.92 & & & $1-3$ \\
MGT & 1. BA & 73 & 47.32 & & & \\
& 2. MA & 44 & 34.28 & 4.609 & 0.650 & \\
& 3. PhD & 11 & 29.67 & & & \\
GEC & 1. BA & 73 & 40.43 & & & \\
& 2. MA & 44 & 50.58 & 7.243 & 0.042 & $1-2$ \\
& 3. PhD & 11 & 42.28 & & & $1-3$ \\
\hline
\end{tabular}

Abbreviations: GM: Grammar Methodology, MGT: Materials in Grammar Teaching, GEC: Grammar Error Correction

The results of the test reveal that teachers' degrees create a significant difference in their attitudes in terms of methodology and error correction techniques in grammar classes $(\mathrm{p}<.05)$. Considering the materials to be used in grammar courses, there was no significant difference in teachers' attitudes when their degrees taken into account. The reason in why factors (GM and GEC) related to the methodology and error correction significant differences were seen but not in the factor (MGT) related to the materials, could stem from the language programs the participants are working in. In some language schools, a strict syllabus is followed and all the staff in the faculty have to obey the rules administered so as to keep up with the syllabus. Therefore, they cannot have a lot to say with the materials they can use in grammar classes and this fact can be the reason why no significant difference was seen in that factor. On the other hand, when we consider the other factors including the methodology and error correction in grammar courses, teachers are free to use their own techniques in teaching grammar as long as they are effective and not rejected by the learners. For that reason, when their academic degrees are taken into account, a significant difference in those two factors occurred because of their personal differences in choosing the appropriate ways to teach grammar and correct their students' errors.

\section{DISCUSSION AND CONCLUSIONS}

This study was carried out in 2015 and it was aimed to design a scale to examine language teachers' attitudes towards teaching grammar and to analyze those attitudes with regard to a number of independent variables like gender, age, graduate faculty and degrees obtained by the participants. Out of 251 volunteers from the language schools of 
Eskişehir Anadolu University, Eskişehir Osmangazi University and Kütahya Dumlupinar University, 247 language instructors whose ages ranged from 22-51 were included in the study. Most of these participants held BA degrees, and as for the educational backgrounds, they were mostly ELT graduates. Non-parametric statistical tests such as Mann Whitney U and Kruskal Wallis were used and the findings revealed that the scale which has 3 factors including grammar methodology, materials and error correction techniques was reliable in determining the attitudes of language teachers.

Findings driven from the statistical analysis showed that gender does not play an important role on the attitudes of teachers towards grammar teaching and therefore does not create a significant difference in their beliefs. However, age creates a significant difference in the attitudes of teachers' towards teaching grammar and it is inferred that especially language teachers over the age of 38 may have significantly different attitudes towards grammar teaching when compared to their younger colleagues. Another important finding from the study revealed that teachers' work experience may also play an important role on their attitudes towards teaching grammar. Experienced teachers were found to act significantly different from less experienced teachers and this might affect their decisions in grammar classes in terms of error correction, materials of teaching and the way they teach grammar. It was also found that graduate faculty of teachers does not create a significant difference in their attitudes towards grammar teaching. Another independent variable that could affect teachers' attitudes was considered as the degrees obtained by the teachers and it was found that teachers' degrees create a significant difference in their attitudes in terms of methodology and error correction techniques in grammar classes whereas in terms of the materials to be used in grammar courses, there was no significant difference in their attitudes. For the reasons of this difference, the language programs in which the participants work could have been effective factors since predetermined syllabi are followed and all the staff in the faculty have to obey the rules administered so as to keep up with the curriculum.

In addition to those statistical findings it was also found that most of the participants (89\%) believe that grammar should not be taught implicitly and within the rules. Participants believed that explicit grammar teaching will be much better and grammar should be taught in a context if it is possible. By this way it was inferred that learners benefit more from the grammar courses and use the newly learnt grammar forms more often. Furthermore it was found that most of the language teachers prefer to use the target language in their grammar courses, however, their learners want the instructors use their native tongues in grammar courses to make the rules easier to understand. Teachers however want their learners hear and grasp as more language as they can while teaching grammar since they believe that grammar forms are best learned if they are used often, error free and in a meaningful context.

In terms of error correction, participants stated different opinions in terms of the frequency and the timing of error correction. Participants generally (71\%) tend not to correct the errors of the learners immediately and they mostly stated that error correction is not really necessary to be made by the teachers if enough time is given to the learners to make self or peer correction. The main aim of the teachers appeared to let the learners 
use as much language as they could in grammar lessons regardless of the mistakes they do, because in time the more the rules are acquired the more corrections will be made not only by the learners themselves but also by their peers.

Similar to the study carried out by Uysal \& Yavuz (2015) it was clear that participants' age and work experience influence their attitudes in grammar teaching. Younger teachers tend to focus more on communicative language tools to teach grammar whereas more experienced teachers still keep on using the grammar course books since they believe that they are not only rich in terms of grammar practice but also provide the learners with a guide book that they may use whenever they need implicit grammar rules. Nut much evidence was present in terms of participants graduate faculties in different studies but in terms of the academic degrees the participants have no significant difference was found in their attitudes towards grammar teaching.

Besides these conclusions, some suggestions that might help other researches should also be made for the future studies on teachers' attitudes towards grammar teaching. First of all the participants of this study were working in state schools and their attitudes could have been much more different from their colleagues working in private universities, so a study including the views of both parties could be made to see if their views on this matter cause a remarkable difference. In addition, a study including more participants and more state universities (or high schools maybe) could give a more vivid view to analyze the teachers' attitudes because it could have been a limitation of this study that only university teachers were included. The last but not the least, a qualitative research to collect teachers' attitudes towards grammar teaching can also be made to gain more data and detailed expressions of the participants to better answer the questions including their justifications regarding the attitudes towards grammar teaching.

To conclude, in this study a sample procedure on how to develop a scale for social studies and how its psychometric properties were determined was explained in details and it can help other researchers carry out similar studies for different research topics. Furthermore, with this new scale TEGAS on determining the attitudes of language teachers' attitudes towards teaching grammar, researchers could have a chance to make similar studies in their own contexts, collect data and make comparisons using the findings of this study with their own results.

\section{REFERENCES}

Al-Mekhlafi, A., \& Nagaratnam, R. P. (2011). Difficulties in teaching and learning grammar in an EFL context. International Journal of Instruction, 4(2), 69-92.

Anderson, J. C., \& Gerbing, D. W. (1984). The Effect of sampling error on convergence, improper solutions, and goodness of fit indices for maximum likelihood confirmatory factor analysis . Psychometrika, 49, 155-73.

Azad, A. K. (2013). Grammar Teaching in EFL Classrooms: Teachers' Attitudes and Beliefs. ASA University Review, Vol. 7 No. 2, July-December, 2013. On 07.08.2017 Retrived from: http://www.asaub.edu.bd/data/asaubreview/v7n2s110.pdf 
Bentler, P. M. (1990). Comparative fit indexes in structural models. Psychol Bull, 107(2), 238-246.

Borg, S. (2003). Teacher cognition in grammar teaching: A literature review. Language Awareness, 12(2), 96-108.

Browne M. W., \& Cudeck, R. (1989). Single sample cross-validation indexes for covariance structures. Multivariate Behavioral Research, 4(24), 445-55.

Büyüköztürk, Ş. (2013). Sosyal bilimler için veri analizi el kitabı. Ankara: Pegem.

Canale, M., \& Swain, M. (1980). Theoretical bases of communicative approaches to second language teaching and testing. Applied Linguistics, 1(1), 1-47.

Cohen, R. J., \& Swerdlik, M. E. (2013). Psikolojik test ve değerlendirme, testler ve ölçmeye giriş (E. Tavşancıl, Trans.). Ankara: Nobel.

Crocker, L., \& Algina, J. (1986). Introduction to classical and modern test theory. USA: CBS Collage Publishers Campany.

Çokluk, Ö., Şekercioğlu, G., \& Büyüköztürk, Ş. (2010). Sosyal bilimler için çok değişkenli istatistik. Ankara: Pegem Akademi.

DeVellis, R. F. (2014). Ölçek geliştirme, kuram ve uygulamalar (T. Totan, Trans.). Ankara: Nobel.

Doğan, İ., \& Doğan, N. (2014). Adım adım çözümlü parametrik olmayan istatistiksel yöntemler. Ankara: Detay.

Doughty, C., \& Williams, J. (1998). Pedagogical choices in focus on form. In Doughty, C., \& Williams, J. (Ed). Focus on form in classroom second language acquisition (pp. 197-261). Cambridge: Cambridge University Press.

Ellis, R. (2006). Current issues in the teaching of grammar: An SLA perspective. TESOL Quarterly, 40(1), 83-106.

Glaser, D. N. (2002). Review of structural equation modeling: Foundation and extensions by David Kaplan. Structural Equation Modeling, 9, 141-150.

Green, S. B., \& Salkind, N. J. (2008). Using SPSS for windows and macintosh. New Jersey: Pearson Prentice Hall.

Hedge, T. (2000). Teaching and learning in the language classroom. Oxford, England:Oxford University Press.

Hu L. T., \& Bentler P. M. (1999). Cut off criteria for fit indexes in covariance structure analysis: conventional criteria versus new alternatives. Structural Equation Modeling: A Multidisciplinary Journal, 6 (1), 1-55.

Jöreskog, K. G., \& Sörbom, D. (1993). Lisrel 8: Structural equation modeling with the simplis command language. Hillsdale: Erlbaum Associates Publishers.

Kline, R. B. (2005). Principles and practice of structural equation modeling. NewYork: The Guilford Press. 
Krashen, S. (1982). Principles and practice in second language acquisition. Oxford, England: Pergamon.

Lightbown, P. (1991). What have we here? Some observations on the effect of instruction on L2 learning. In R. Phillipson, E. Kellerman, L. Selinker, M. Sharwood Smith, \& M. Swain (Ed), Foreign/second language pedagogy research (pp. 197-212). Clevedon, England: Multilingual Matters.

Loewen, S., Li, S., Fei, F., Thompson, A., Nakatsukasa,K.,Ahn, S., \& Chen, X. (2009). Second language learners' beliefs about grammar instruction and error correction. The Modern Language Journal, 93, 91-104.

Marsh, H. W., Balla, J. R., \& McDonald, R. P. (1988). Goodness-of-fit indices in confirmatory factor analysis: The effect of sample size. Psychological Bulletin, 103(3), 391-410.

Marsh, H. W., Balla, J. R., \& Hau, K. T. (1996). An evaluation of incremental fit indices: A clarification of mathematical and empirical properties. In G. A. Marcoulides \& R. E. Schumacker (Ed), Advanced structural equation modeling: Issues and techniques (pp. 315-353). Mahwah, NJ: Lawrence Erlbaum Associates, Inc.

Özdamar, K. (2013). Paket programlar ile istatistiksel veri analizi. Eskişehir: Nisan.

Şeker, H., \& Gençdoğan, B. (2014). Psikolojide ve eğitimde ölçme aracı geliş̧tirme. Ankara: Nobel.

Siegel, S. (1977). Davranış bilimleri için parametrik olmayan istatistikler (Y. Topsever, Trans.). Ankara: Ankara Üniversitesi Basımevi.

Sümbüloğlu K., \& Akdağ B. (2009). Illeri biyoistatistiksel yöntemler. Ankara: Hatipoğlu.

Sümer, N. (2000). Yapısal eşitlik modelleri: Temel kavramlar ve örnek uygulamalar. Türk Psikoloji Yazllarl,3 (6), 49-73.

Şimşek, Ö. F. (2007). Yapısal eşitlik modellemesine giriş: Temel ilkeler ve LISREL uygulamaları. İstanbul: Ekinoks.

Thornbury, S. (1997). Grammar, power and bottled water. IATEFL Newsletter , 140.

Thu, T. H. (2009). Teachers' Perceptions About Grammar Teaching. On 07.08.2017 Retrived from: http://files.eric.ed.gov/fulltext/ED507399.pdf

Ur, P. (1996). A course in language teaching. England: Cambridge University Press.

Uysal, N. D., \& Yavuz, F. (2015). Pre-service teachers' attitudes towards grammar teaching. Procedia - Social and Behavioral Sciences. 191(2), 1828-1832. https://doi.org/10.1016/j.sbspro.2015.04.353

Vieira, A. L. (2011). Preparation of the analysis. Interactive LISREL in practice. London: Springer.

Zaal, F. (2013). Attitudes towards Grammar Teaching. Advanced Writing: Linguistic $\begin{array}{lllll}\text { Specialism. On 7.8.2017 Retrived from http://www.diva- } & \text { On }\end{array}$ ..portal.org/smash/get/diva2:662497/FULLTEXT01.pdf 
Turkish Abstract

Öğretmenlerin İngilizce Dilbilgisi Öğretimine Yönelik Tutumları: Bir Ölçek Geliştirme Çalısması

$\mathrm{Bu}$ çalışma, İngilizce öğretimi sürecinde öğretmenlerin dilbilgisi rolüne yönelik tutumlarını belirleyen bir ölçek tasarlamak ve bu ölçeğin güvenilirliği ve geçerliliği gibi psikometrik özelliklerini belirlemek amacıyla yapılmıştır. Ölçek iki aşamalı olarak geliştirilmiş; ilk olarak ölçeğin faktör yapısını keşfetmek, daha sonra öğelerin araştırılmasından elde edilen yapıyı teyit etmek amaçlanmıştır. Araştırmaya yönelik ve doğrulayıcı faktör analizlerinin sonuçları, bu çalışmada geliştirilen ölçeğin üç faktörü içeren oldukça geçerli ve güvenilir bir veri toplama aracı olduğunu ortaya koymuştur.

Anahtar Kelimeler: dilbilgisi, öğretmen tutumu, ölçek geliștirme, araştırmaya yönelik faktör analizi, doğrulayıcı faktör analizi

\section{French Abstract}

Les attitudes de Professeurs Envers Enseignement de Grammaire Anglaise: Une Etude de Développement D'échelle

Cette étude a eu pour but de concevoir une échelle qui identifie les attitudes des professeurs vers le rôle de grammaire dans le processus d'enseigner l'anglais, au pilote cela et découvrir les qualités psychométriques comme la fiabilité et la validité de l'échelle conçue. L'échelle a été développée en deux phases; il a été d'abord visé pour explorer la structure de facteur de l'échelle, ensuite confirmer la structure gagnée de l'exploration des articles. Les résultats d'analyses de facteur exploratoires et confirmatives ont révélé que l'échelle développée dans cette étude était un outil de collecte de données considérablement valable et fiable incluant trois facteurs.

Mots Clés: la grammaire, l'attitude de professeur, pèse le développement, l'analyse de facteur exploratoire, l'analyse de facteur confirmative

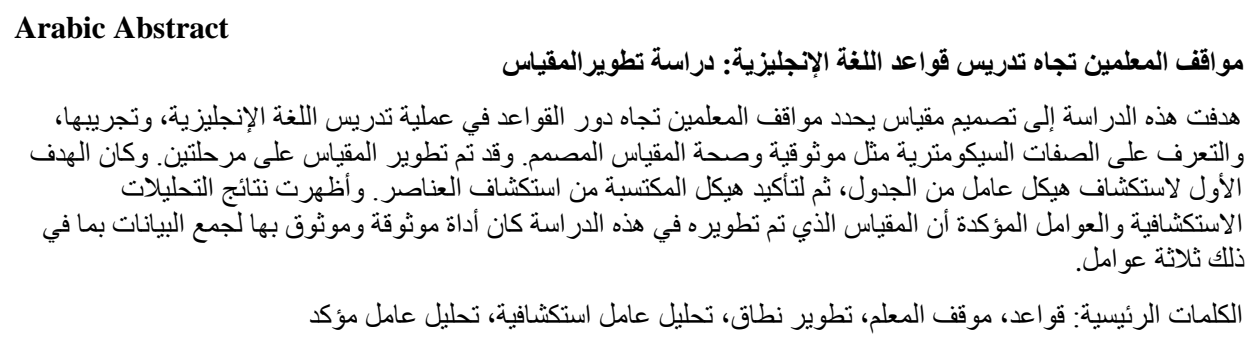




\section{German Abstract \\ Die Einstellung der Lehrer zum Unterrichten der Englischen Grammatik: Eine Skalenentwicklungsstudie}

Diese Studie zielte darauf ab, eine Skala zu entwerfen, die die Einstellung der Lehrer zur Rolle der Grammatik im Prozess des Unterrichts von Englisch identifiziert, um sie zu piloten und die psychometrischen Qualitäten wie Zuverlässigkeit und Gültigkeit der Skala zu entdecken. Die Skala wurde in zwei Phasen entwickelt; Es war zunächst darauf ausgerichtet, die Faktorstruktur der Skala zu erforschen, um dann die Struktur zu bestätigen, die aus der Erforschung der Gegenstände gewonnen wurde. Die Ergebnisse der explorativen und bestätigenden Faktorenanalysen zeigten, dass die in dieser Studie entwickelte Skala ein beträchtlich gültiges und zuverlässiges Datenerfassungswerkzeug mit drei Faktoren war.

Schlüsselwörter: grammatik, lehrerhaltung, skalenentwicklung, explorationsfaktoranalyse, bestätigungsfaktoranalyse

\section{Malaysian Abstract Sikap Guru Terhadap Pengajaran Bahasa Inggeris: Kajian Pembangunan Skala}

Kajian ini bertujuan untuk mereka bentuk skala yang mengenal pasti sikap guru terhadap peranan tatabahasa dalam proses pengajaran Bahasa Inggeris, untuk memperjuangkannya, dan untuk mengetahui kualiti psikometrik seperti kebolehpercayaan dan kesahan skala yang direka. Skala ini dibangunkan dalam dua fasa; ia mula-mula bertujuan untuk meneroka struktur faktor skala, kemudian untuk mengesahkan struktur yang diperolehi dari penerokaan item. Hasil analisa faktor eksplorasi dan pengesahan menunjukkan bahawa skala yang dibangunkan dalam kajian ini adalah alat pengumpulan data yang agak sah dan boleh dipercayai termasuk tiga faktor.

Kata Kunci: tatabahasa, sikap guru, pembangunan skala, analisis faktor penerokaan, analisis faktor pengesahan

\section{Russian Abstract \\ Отношение Учителей к Преподаванию Английской Грамматики: Исследование Развития Масштабов}

Это исследование предназначалось для разработки шкалы, которая идентифицирует отношение учителей к роли грамматики в процессе обучения английскому языку, пилотировать ее и выяснить психометрические качества, такие как надежность и обоснованность разработанной шкалы. Масштаб был разработан в два этапа; сначала было предложено исследовать факторную структуру шкалы, затем подтвердить структуру, полученную при исследовании предметов. Результаты поискового и подтверждающего факторного анализа показали, что масштаб, разработанный в этом исследовании, был значительно надежным инструментом сбора данных, включающим три фактора.

Ключевые Слова: грамматика, отношение учителя, развитие шкалы, анализ исследовательских факторов, анализ подтверждающих факторов 